\title{
UPDATE ON ONGOING TANK CAR CRASHWORTHINESS RESEARCH: PREDICTED PERFORMANCE AND FABRICATION APPROACH
}

\author{
Michael Carolan \\ Brandon Talamini \\ David Tyrell \\ Volpe National Transportation Systems Center \\ US Department of Transportation \\ Cambridge, MA 02142
}

\section{ABSTRACT}

Research is currently underway to develop strategies for maintaining the structural integrity of railroad tank cars carrying hazardous materials during collisions. This research, sponsored by the Federal Railroad Administration (FRA), has focused on four design functions to accomplish this goal: blunting the impact load, absorbing the collision energy, strengthening the commodity tank, and controlling the load path into the tank. Previous papers have been presented outlining the weight and space restrictions for this new design, as well as the approach being taken in developing the design. The performance goals for the new car have also been outlined. A key goal for the new design is the ability to contain its lading at four times the impact energy of the baseline equipment.

Presently, a preliminary design has been developed that will incorporate these four functions together. This new design features a conventional commodity tank with external reinforcements to strengthen the tank. The reinforced tank is situated on a structural foam cradle, within an external carbody. This carbody has been designed utilizing welded steel sandwich panels. The body is designed to take all of the inservice loads, removing the commodity tank from the load path during normal operations. Additionally, the carbody panels will serve as an energy-absorbing mechanism in the event of a collision.

Preliminary steps for fabricating and assembling the new tank car design have been outlined. These steps were developed with the intention of paralleling existing tank car fabrication process as much as is practical.

Using the commercial finite element analysis (FEA) software ABAQUS/Explicit, the improved design has been analyzed for its response to an impact by a rigid punch. Simulations of two generalized impact scenarios have been made for this rigid punch impacting the improved tank car head as well as the improved tank car shell. Results of these analyses, including the force-displacement curves for both impacts, are presented within this paper. These results show that an improved-design tank car can contain the commodity for a head impact with eight times the energy of the baseline car, and four times the energy for a shell impact.

\section{INTRODUCTION}

Presently, the Pipeline and Hazardous Material Safety Administration (PHMSA) and the Federal Railroad Administration (FRA) are engaged in ongoing railroad tank car safety rulemaking. As a part of the rulemaking effort, the Volpe National Transportation Systems Center (Volpe Center) is conducting research on improving the crashworthiness of these tank cars. Of specific concern are tank cars that carry materials classified as a Toxic Inhalation Hazard (TIH).

A previous publication has given a background on the need for an improved-crashworthiness design tank car, as well as the key design requirements, the physical constraints on weight and space available for new components, and the desired kinematics of the tank car during an impact [1]. Additional papers supporting this research effort have been published on the topics of full-scale impact testing of the baseline tank car [2], material failure modeling [3], collision dynamics modeling [4], and an overview of the research effort in support of the PHMSA and FRA rulemaking activity [5]. A companion paper describes the detailed finite-element modeling performed on the baseline tank car [6].

\section{IMPROVED DESIGN DEVELOPMENT}

A key design goal for the improved-crashworthiness tank car is the ability to protect its lading at four times the impact

This material is declared a work of the U.S. Government and is not subject to copyright protection in the United States. Approved for public release; distribution is unlimited. 
energy as the baseline equipment. This energy goal is to be met in two generalized impact scenarios. These scenarios were defined by previous investigations of tank car accident dynamics [4], and are shown schematically in Figure 1. Each impact scenario involves the tank car being impacted by a ram car, loaded to a standard freight car weight $(286,000 \mathrm{lb})$, with the impact caused by a 6 in by 6 in square face punch.

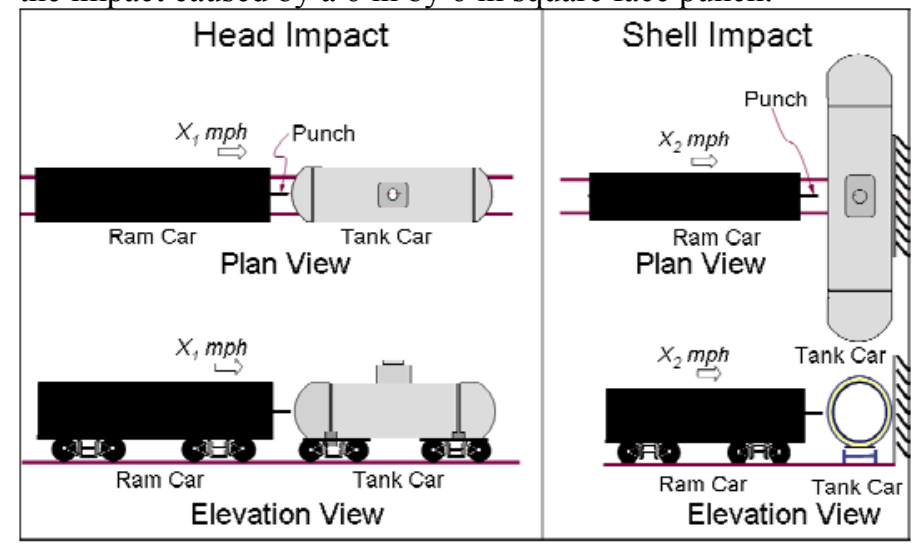

Figure 1 - Schematic of Head and Shell Impact Scenarios

\section{Selected Concept}

In order to meet the performance goals set forth for the improved-design tank car, a number of intended functions must be accomplished. Design features have been selected that can accomplish the desired functions. Specific forms have been chosen as part of the preliminary design in order to implement the features. The preliminary improved-design tank car is shown in Figure 2.

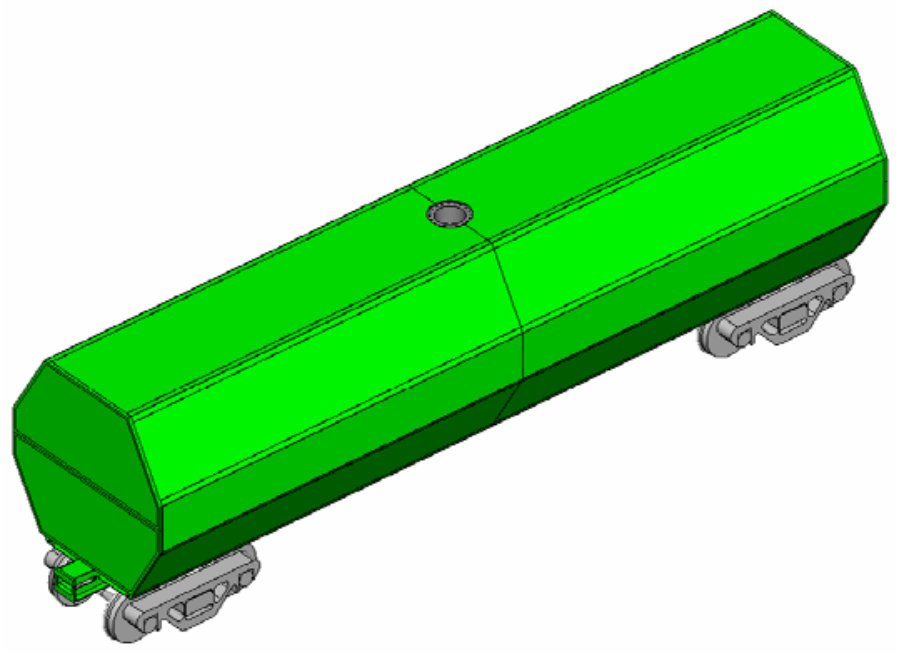

Figure 2 - Preliminary Design Concept
Table 1 - Preliminary Design Functions, Features, and Forms

\begin{tabular}{|c|c|c|}
\hline Functions & Features & Forms \\
\cline { 1 - 2 } $\begin{array}{c}\text { Blunted impact } \\
\text { loads }\end{array}$ & $\begin{array}{c}\text { Sacrificial structure } \\
\text { that shields tank } \\
\text { and absorbs } \\
\text { energy } \\
\text { absorbed }\end{array}$ & $\begin{array}{c}\text { Dual-purpose } \\
\text { Sandwich Structures }\end{array}$ \\
\hline $\begin{array}{c}\text { Stronger tank } \\
\text { Reinforcement of } \\
\text { head and shell }\end{array}$ & $\begin{array}{c}\text { Randwich Panels } \\
\text { Sand Head, } \\
\text { Over Shell }\end{array}$ \\
\hline $\begin{array}{c}\text { Control load } \\
\text { path to tank }\end{array}$ & $\begin{array}{c}\text { Detach tank from } \\
\text { service loads }\end{array}$ & Separate Carbody \\
\hline
\end{tabular}

Engineered sandwich panels have been selected as the primary form to accomplish multiple functions in the improved design. Sandwich panels offer a number of advantages over alternative construction materials and techniques [7]. They possess the ability to support loads in the plane of the panel while offering effective energy-absorbing capability in the normal (out-of-plane) direction [8], as well as a high bending resistance. A variety of core geometries are available to be used within the sandwich panel, including honeycombs, egg crate, and wave patterns. A typical sandwich panel, with a wave pattern core structure, is shown in Figure 3.

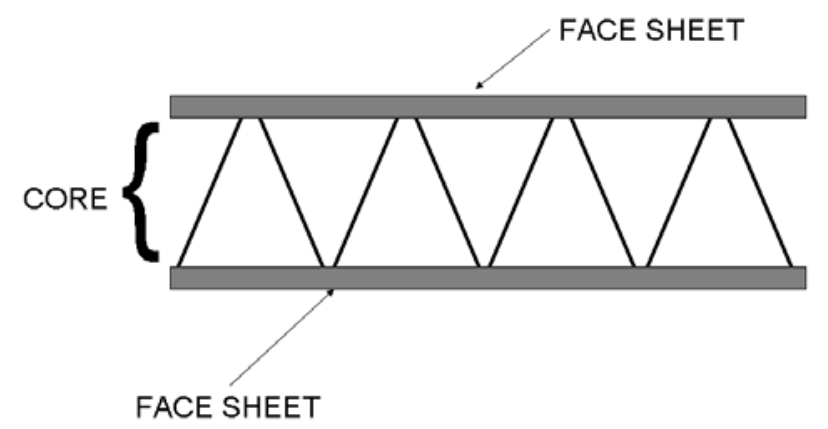

Figure 3 - Annotated Sandwich Panel

The preliminary design described in this paper consists of a conventional tank reinforced with sandwich panels around the shell and stiffeners around the head. This tank sits within a structural carbody, also composed of sandwich panels. Between the reinforced tank and the carbody is a structural foam saddle, designed to support the tank while isolating it from the service loads in the carbody. A cutaway view of the preliminary design is shown in Figure 4.

Table 1 lists the design features and their associated functions and forms that have been developed for the preliminary design.

This material is declared a work of the U.S. Government and is not subject to copyright protection in the United States. Approved for public release; distribution is unlimited. 


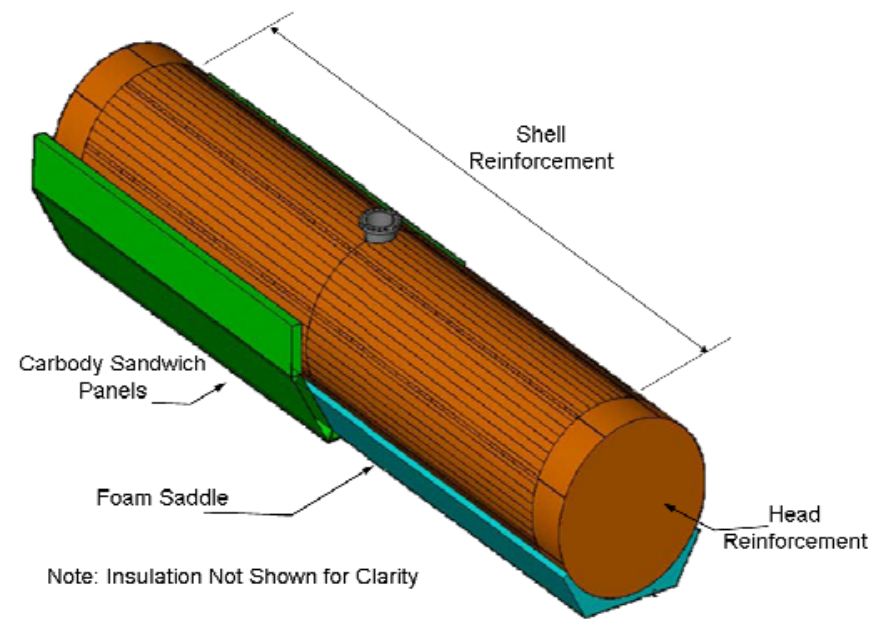

Figure 4 - Cutaway View of Preliminary Design

One type of sandwich panel utilized in the preliminary design will make up the external carbody. This structure is to accomplish three of the functions seen in Table 1; blunting the impact loads, absorbing collision energy, and controlling the load path to the tank. The majority of the time, the carbody will be in normal service. It must be able to function as any other railcar body does, taking the buff and draft forces as well as the suspension loads. Additionally, the carbody must meet all of the applicable regulations and standards in order to enter service as a railcar.

As part of the improved crashworthiness of the new design, the carbody has been designed to incorporate two additional functions: blunting the impact load and absorbing collision energy. By blunting the impact load, the tank will be loaded over a greater area, enabling more collision energy to be absorbed before failure of the commodity tank [1]. By incorporating an energy-absorbing component external to the tank, the loading demands on the tank can be further reduced during an impact. The impacting object will be traveling with a decreased speed by the time the commodity tank is being loaded, requiring the tank to absorb less collision energy [1]. The outer carbody sandwich panel is currently envisioned as square honeycomb core.

In addition to carrying the commodity, the tank acts as a foundation for any external structures during a collision. In order to function properly, the energy-absorbing carbody must deform before the commodity tank. Since the load path of an impacting object can transmit force through the carbody and into the commodity tank, it is necessary to reinforce the commodity tank to absorb the required energy levels.

A second type of sandwich panel can be used to accomplish this task. A series of curved panels designed to fit snugly against the shell of the tank will provide reinforcement to the tank, as well as absorb some amount of collision energy. These panels are designed to provide a stiffer load-indentation response than the baseline tank.

\section{DEVELOPMENT OF FABRICATION APPROACH}

During the development of this design, an effort was made to utilize existing tank car construction practice wherever appropriate and practical. This includes the use of some offthe-shelf railcar components.

The construction sequence developed for this preliminary design can be broken into three distinct phases: construction of the reinforced tank, construction of the carbody, and the final assembly of the tank and carbody to complete the tank car.

\section{Phase I: Construction of the Reinforced Tank}

The first phase of construction bears a number of similarities to the construction of a conventionally-built railroad tank car. The tank, consisting of a number of steel rings and a pair of steel heads, is assembled using conventional practices. After the heads have been formed, a number of precut steel arches are welded to both tank heads. These arches are then further reinforced with small rectangular steel plates to form a spider web pattern, as shown in Figure 5. A thin steel face sheet can then be welded over the arches. This arrangement of reinforcements reduces the "snap-through" response of the baseline tank head [9].

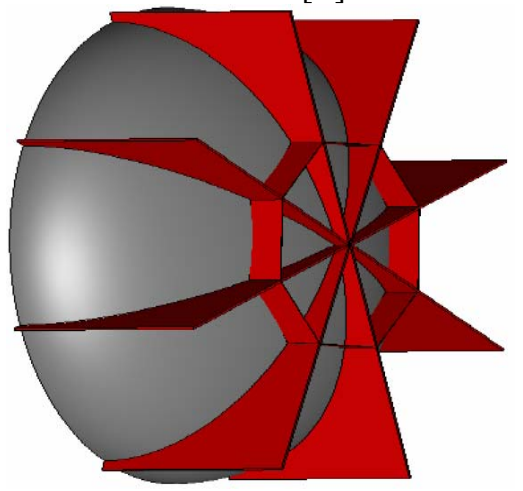

Figure 5 - Tank Head with Reinforcing Arches

A different approach is utilized to strengthen the shell of the tank than was used to strengthen the head. Because of the considerable surface area involved, it is not practical to weld a series of individual reinforcements in the same manner as applied to the tank heads. Instead, a series of reinforcing sandwich panels can be manufactured separately from the rest of the tank and installed at a late stage of the tank's assembly.

The sandwich panels needed to reinforce the tank must be snug-fitting against the outer surface of the tank. This necessitates the use of a curved sandwich panel. The panels may be bonded to the surface of the tank to prevent slippage and to carry shear loads.

The design of the reinforcement panels takes advantage of the ability to embed multiple orientations of material within the core. The final assembly of the reinforced tank is made easier by the ability to bolt adjacent panels to one another. Hence, the outermost member of each reinforcement panel can be a square or rectangular section with appropriate bolt hole placement.

This material is declared a work of the U.S. Government and is not subject to copyright protection in the United States. Approved for public release; distribution is unlimited. 
The design of the reinforcement panels calls for one end of a given panel to have this member attached to the top face sheet (Panel A) while the other end of the panel has this member attached to the bottom (Panel B), to facilitate the mating of adjacent panels during assembly. This design, applied to two adjacent panels, is shown in Figure 6.

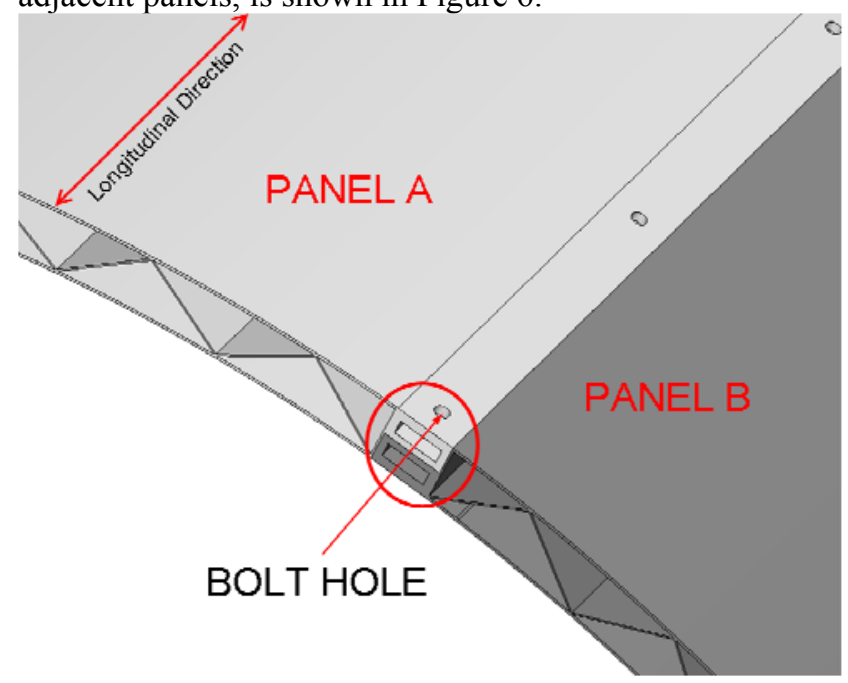

Figure 6 - Adjacent Reinforcement Panels

Once a panel is in the proper position around the circumference of the tank, it is bolted to the adjacent panel along the entire length of the mating surfaces. The next panel along the circumference can be installed, until the entire tank has been reinforced. This installation sequence is shown in Figure 7.

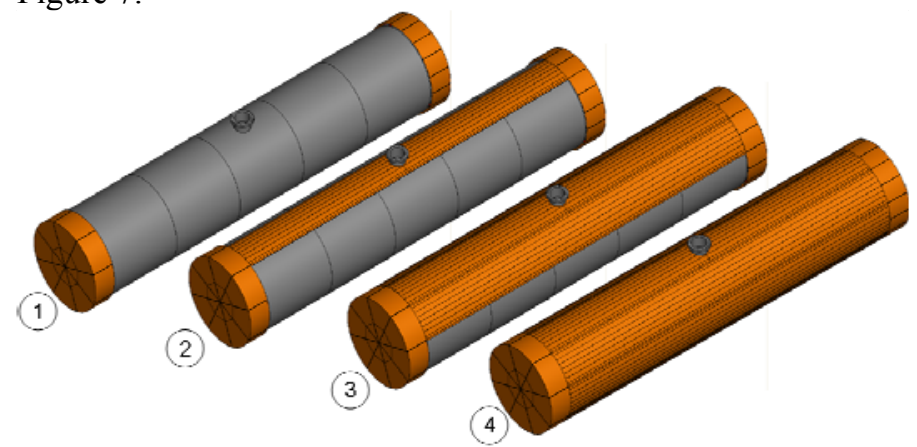

Figure 7 - Shell Reinforcing Panel Installation Sequence

The reinforced tank is complete with the installation of the reinforcing panels surrounding the shell. The tank will move on to Phase III for incorporation into the external carbody.

\section{Phase II: Construction of the External Carbody}

While the construction of the individual components that make up the carbody are presented here in a sequential manner, it is anticipated that manufacturers of the carbody will determine their own sequence.

In order to meet the requirements of normal service as well as achieve impact blunting and energy absorption during a collision, a series of sandwich panels are utilized for the carbody as well. The underframe of the car is incorporated within one such panel. This panel is constructed upside-down, with what will become the top face sheet prepared first. A continuous center sill can be attached directly to the face sheet. Two body bolsters can also be incorporated within the core of the sandwich panel. The energy-absorbing core structure would be welded to the face sheet at this point in the assembly.

With the center sill, body bolsters, and core structure attached to the top facesheet, the bottom facesheet can be welded to the core. Finally, the draft sill components can be welded into the proper place. The sequence of construction of the underframe panel is shown in Figure 8. For clarity, this figure shows the panel from one draft sill to the centerline. The full-length panels are symmetric about the center. The body bolsters and core structure are not shown in this figure. The coupler and draft gear may be installed at this point or at any subsequent point in the assembly.
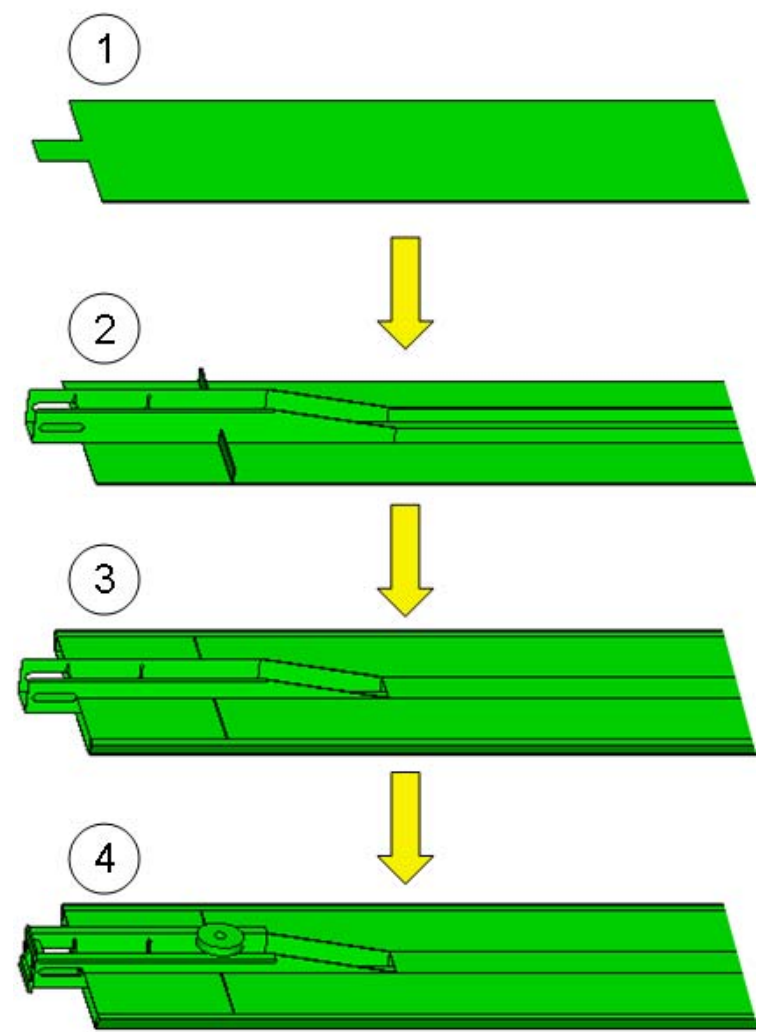

Figure 8 - Underframe Sandwich Panel Sequence

The sidewalls and head panels of the carbody are also to be constructed of sandwich panels. The process for manufacturing them is essentially the same as the underframe, but is simplified by the absence of the center sill and body bolsters.

Once the underframe panel, sidewall panels, and head panels have been manufactured, the bottom half of the carbody can be assembled. The sidewall panels are held in place and are welded to the underframe panel along both the inner and outer face sheets. The head panels on both ends of the car are then welded into place. At any subsequent point in the

This material is declared a work of the U.S. Government and is not subject to copyright protection in the United States. Approved for public release; distribution is unlimited. 
assembly the bottom half of the carbody may be placed on the trucks, as best suits the manufacturer. The assembled "tub" composed of the underframe panel, sidewall panels, and head panels is shown in Figure 9.

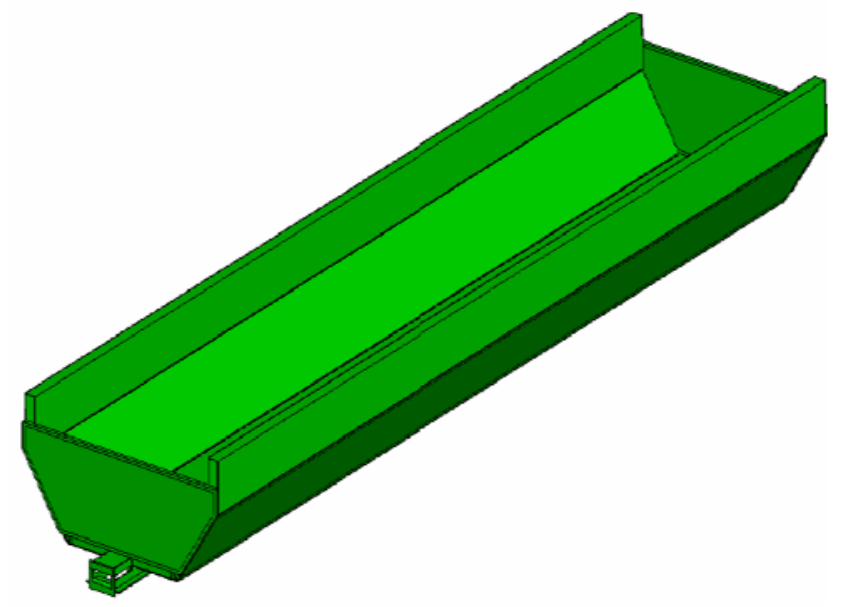

Figure 9 - Assembled Tub

In order to provide complete protection to the tank, the carbody includes a full roof made up of sandwich panels of the same design as the rest of the body. While the roof assembly may be manufactured at this point in the fabrication process, it cannot be mated to the tub of the body yet, as the tank assembly must still be positioned in the tub.

The roof assembly consists of two head panels, two wall panels, and a roof panel. The wall panels feature the same core arrangement as the walls in the tub. The roof panel contains the same core, with additional reinforcement in the area surrounding the cutout for manway access. Similarly to the tub assembly, the wall and roof panels are welded together on both the inner and outer facesheets. The roof assembly, without the head panels, is shown in Figure 10.

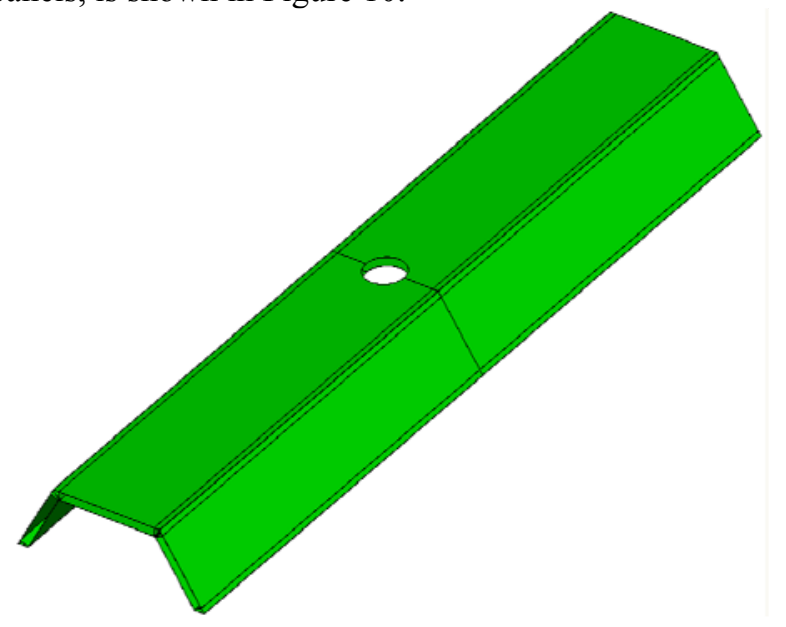

Figure 10 - Roof Assembly

\section{Phase III: Marriage of Tank and Carbody}

Once the reinforced tank has been assembled and the carbody has been manufactured, the two major components can This material is declared a work of the U.S. Government and is not subject to copyright protection in the United States. Approved for public release; distribution is unlimited. be brought together. The tub is first fitted with a full-length foam saddle that is contoured to the shape of the reinforced tank.

This saddle provides support to the tank while isolating it from the service loads being carried in the carbody. The saddle is designed to support the tank across its bottom $120^{\circ}$. Specific fabrication techniques are currently being developed for the appropriate variety of structural foam in this tank car.

The reinforced tank can now be wrapped in appropriate insulation before being lowered onto the foam saddle within the tub. The roof assembly is lowered over the top of the tank within the tub and fixed in place. Finally, the head panels can be attached to the roof assembly.

Figure 11 shows a progression of the assembly of the car around the reinforced tank. Note that in stage 2 the tub is not shown to provide a clear view of the foam saddle. Stage 3 shows the tank within the tub, on the saddle. Stage 4 is the fully-assembled carbody, with the roof assembly's head panels attached. With the structural components of the carbody assembled, the remainder of the running gear can be installed onto the carbody.

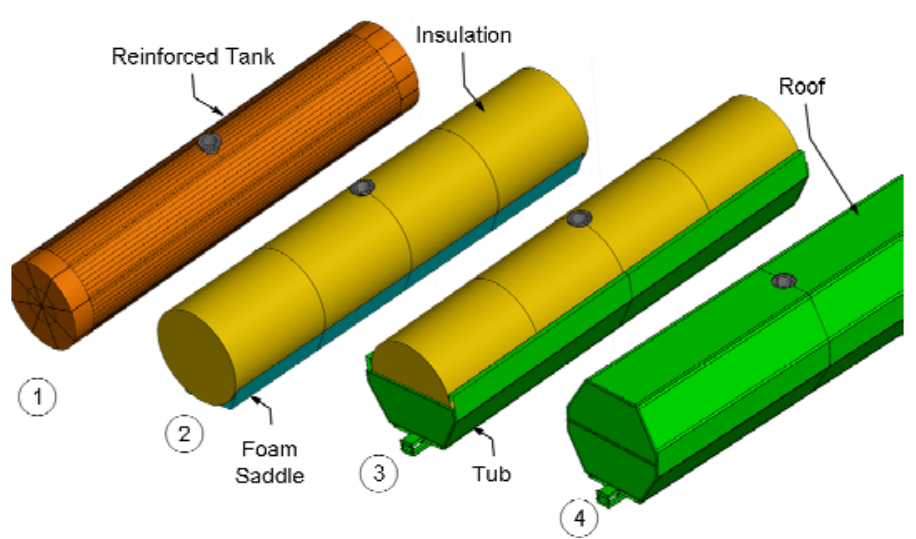

Figure 11 - Progression of Assembly

\section{Weight and Space Budgets}

The commodity tank used in this design is assumed to have a thickness of $5 / 8 \mathrm{in}$. The tank is sized such that the nominal capacity of an existing car of this class is maintained at 17,300 gallons. For clearance purposes, AAR Plate B was chosen for the design limits [10]. The carbody has an extreme width of 128 in, the maximum width allowed. The roof of the carbody is approximately $13 \mathrm{ft}$., $6 \mathrm{in}$. above top-of-rail. The lengths of carbody between truck centers and over the strikers are shown in Figure 12. 


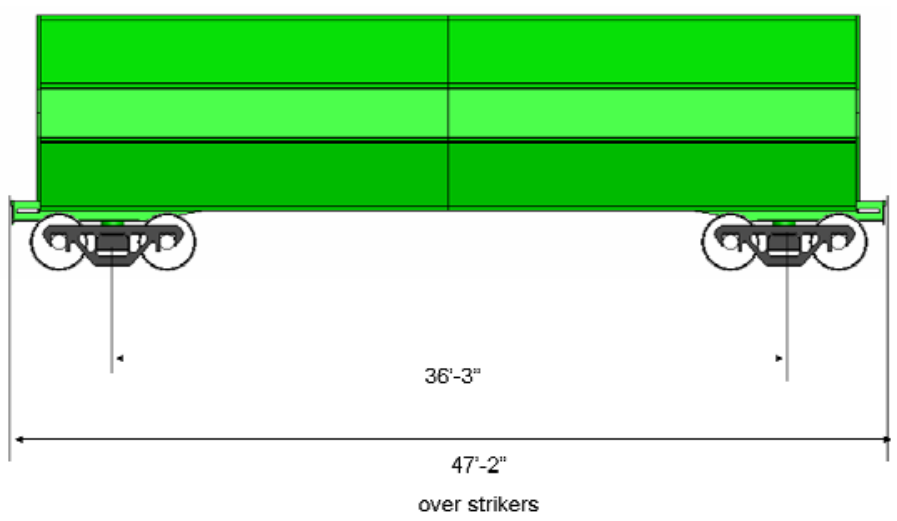

Figure 12 - Carbody Lengths

The preliminary design was developed such that the entire car, when fully loaded, weighs less than 286,000 pounds. The weight estimates, based on the preliminary structures, are shown in Table 2.

Table 2 - Estimated Structure Weight

\begin{tabular}{|l|r|}
\hline Tank Assembly & \\
\hline Bare Tank & 30500 \\
\hline Shell Reinforcement & 12890 \\
\hline Head Reinforcement & 1870 \\
\hline Reinforced Tank & $\mathbf{4 5 2 6 0}$ \\
\hline & \\
\hline Carbody Assembly & \\
\hline Structural Carbody Bottom & 22160 \\
\hline Structural Carbody Top & 11340 \\
\hline Structural Carbody Complete & $\mathbf{3 3 5 0 0}$ \\
\hline & \\
\hline Final Assembly & \\
\hline Saddle Placed in Structural Carbody & 35480 \\
\hline Reinforced Tank Placed in Saddle & 80730 \\
\hline Insulation Applied & 82580 \\
\hline Carbody Placed on Trucks & $\mathbf{1 0 3 1 6 0}$ \\
\hline & \\
\hline Lading & 180000 \\
\hline & \\
\hline Total Weight & $\mathbf{2 8 3 1 6 0}$ \\
\hline
\end{tabular}

\section{IMPACT ANALYSIS}

The effectiveness of the improved design has been compared to the performance objective with finite element analysis using Abaqus/Explicit [11] in the two generalized impact scenarios previously defined. This modeling serves two purposes. First, it must make a reasonable approximation of the impact response of the improved design to determine if the concept is effective. Second, it must guide selection of component sizes and orientations. Hence, the finite element models must capture the salient features of the improved design, but the emphasis is on comparing design iterations on an equal footing and with a quick turnaround. Consistent with this emphasis, the following simplifications have been made:

1. No fluid lading

2. Simplified geometry and boundary conditions

3. No material failure

4. Representation of the carbody sandwich panel core with a continuum element approximation (described below).

These simplifications are being addressed in ongoing work as design details become more certain.

The chief products of the simulations are the punch impact force and the punch displacement (measured from the point of impact). Also of interest is the total absorbed energy, which is the integral of the punch force-displacement curve over the displacement (graphically, this is the area under the punch force-displacement curve). Separate models have been used for the head and shell impact scenarios, each including only the components needed to estimate the force-displacement characteristic. The models are shown in Figures 13 through 16. Note that the sandwich panels shown in Figures 13, 14 and 16 are merely portions of the rest of the carbody (compare to figure 11), but it is not necessary to include the the outer sandwich structure remote from the impact to get an approximate force-displacement response accurate enough for this study.

All car components are made of the tank car steel TC$128 \mathrm{~B}$, with properties as shown in Table 3. Linear elastic behavior has been assumed below the yield strength, while the hardening behavior was computed from the Ramberg-Osgood law:

$\varepsilon=\frac{\sigma}{E}+\left(\frac{\sigma}{K}\right)^{n}$

Stress-plastic strain data pairs were generated using the Ramberg-Osgood law with the constants in Table 3.

Table 3 - Material properties and hardening law constants for TC-128B tank car steel

\begin{tabular}{|l|l|}
\hline Property & Value \\
\hline Young's modulus, $E$ (ksi) & 30,000 \\
\hline Poisson's ratio & 0.3 \\
\hline Yield strength $(\mathrm{ksi})$ & 50 \\
\hline Tensile strength $(\mathrm{ksi})$ & 81 \\
\hline Hardening constant, $K(\mathrm{ksi})$ & 96.8 \\
\hline Hardening exponent, $n$ & 9.41 \\
\hline Weight density $\left(\mathrm{lb} / \mathrm{in}^{3}\right)$ & 0.286 \\
\hline
\end{tabular}

The punch is modeled perfectly rigid and is given an initial closing velocity of $15 \mathrm{mph}$. Additionally, the punch is assigned a weight of $286,000 \mathrm{lb}$, which is the weight of a fully loaded standard freight car.

This material is declared a work of the U.S. Government and is not subject to copyright protection in the United States. Approved for public release; distribution is unlimited. 
The head impact models are illustrated in Figures 13 and 14. Only the affected tank head region is meshed, with 12 in of the cylindrical portion of the tank included to keep the boundary effects from influencing the computed head response. (A study was performed to verify that 12 in is adequate for this purpose). The open end of the tank portion is fully fixed (displacements and rotations) and the punch is constrained to move in the tank longitudinal direction only. The free edges of the carbody sandwich panel segment are left unconstrained. ${ }^{1}$
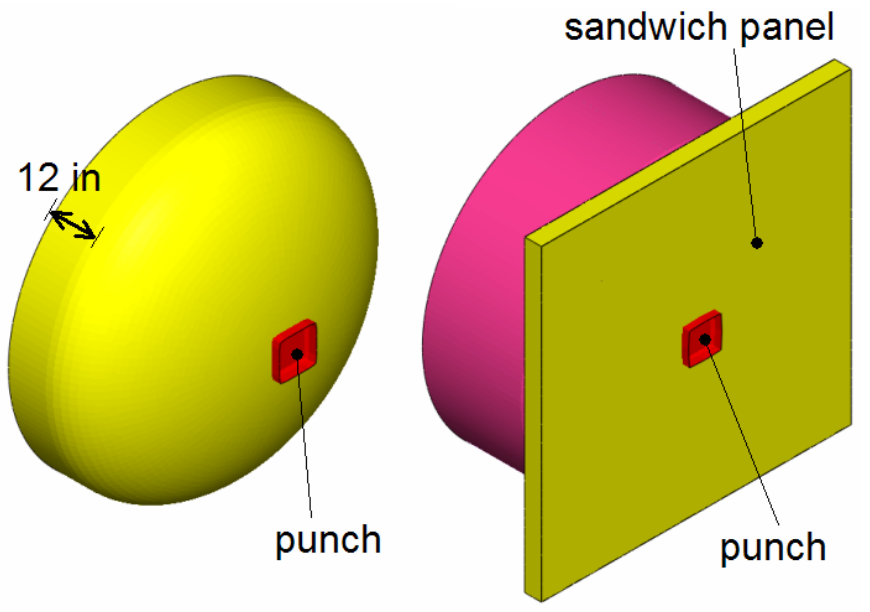

Figure 13 - Left: Baseline Tank Head Impact Model Right: Improved Tank Head Impact Model

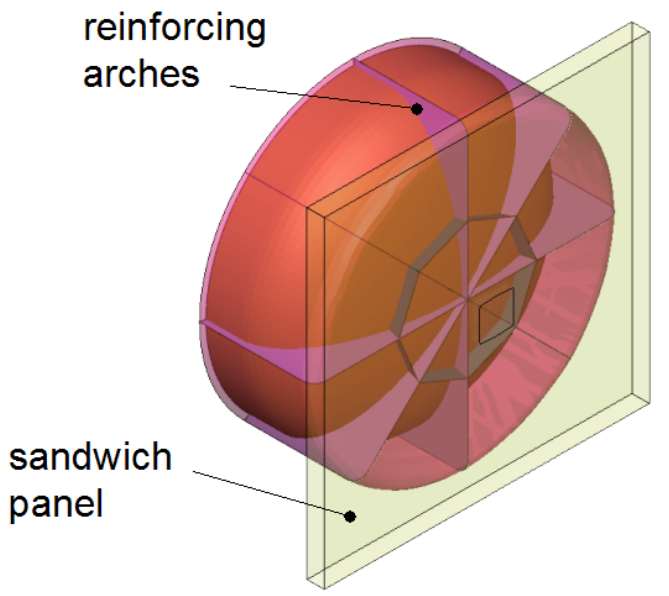

\section{Figure 14 - Improved Tank Head Impact Model, Shown with Translucent Components to Illustrate Hidden Components}

In the shell impact models, the tank is constrained by pinning the centers of both tank heads to ground. The sandwich panel edges are unconstrained. Additionally, the punch is

${ }^{1}$ Fully fixed sandwich panel edges have also been examined, producing similar overall force-displacement characteristics. These boundary conditions are intended to represent the connections of the meshed portions of the outer sandwich panel to the omitted portions. Difficulties in representing these connections with boundary conditions will be obviated in later models where the entire carbody sandwich structure is present in the model.

This material is declared a work of the U.S. Government and is not subject to copyright protection in the United States. Approved for public release; distribution is unlimited. permitted to move only in the direction perpendicular to the tank.

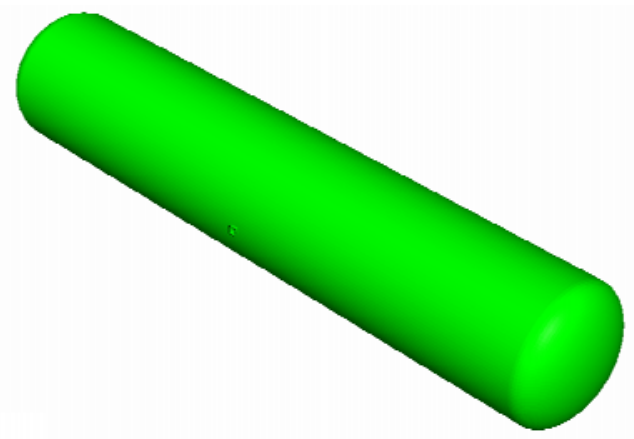

Figure 15 - Baseline Shell Impact Model

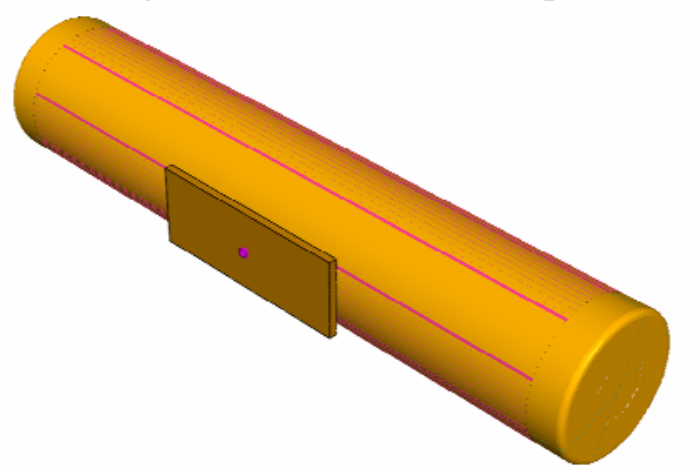

Figure 16 - Improved Shell Impact Model

The tank, reinforcement members and skin, and the outer carbody sandwich face sheets have been modeled with first order quadrilateral shell elements with reduced integration. A small number of triangular elements are utilized to avoid poorly shaped elements. The carbody sandwich panel core has been modeled using a continuum element approximation with the metal foam plasticity model due to Deshpande and Fleck [12]. Xue and Hutchinson successfully employed this technique in preliminary sandwich panel analyses, justifying it as a firstorder approximation of the behavior of the core due to its open nature (i.e., the core undergoes large volume changes during crushing) [13]. Replacing the geometric details of the core with continuum elements permits the core to be modeled economically ${ }^{2}$, in keeping with the stated constraints of these simulations.

The metal foam model parameters have been chosen to match the desired crushing behavior of the sandwich panel. Details of this calibration are in the Appendix. Out-of-plane shearing strength and stretching strength of the core are somewhat overestimated with this technique [14]; subsequent

\footnotetext{
${ }^{2}$ Detailed meshing of the sandwich core requires many elements through the core web depth to capture the collapse mode; this leads to small stable time increments and long computation times. Additionally, a separate buckling eigenmode calculation must be performed to seed imperfections into the mesh. The continuum approximation can achieve reasonable accuracy for the purposes of a preliminary design evaluation with a single element through the core depth.
} 
analysis (not included in this paper) is being conducted with a continuum plasticity law approximation developed especially for structural sandwich cores due to Xue and Hutchinson [14] that mitigates this effect. Nevertheless, the metal foam approximation provides useful information on the sandwich panel response and is suitable for the preliminary design assessment here.

\section{Head Impact Results}

For reasons stated in the previous section, failure is not computed directly in the finite element code. The failure point must be estimated to compare the approximate energy absorption totals for the baseline and improved designs. For the baseline tank, failure is assumed to occur at approximately 12 in. of indentation, based on experience with testing and modeling of tank cars $[2,6]$. An approximate measure of tank failure has been used for the improved design: the punch was allowed the same displacement as the baseline tank, plus the thickness of the sacrificial structure. The reinforcement is approximately 2 in. thick and the external carbody sandwich panel is approximately 6 in. thick, so the improved design is assumed to fail at $20 \mathrm{in}$. of impactor displacement.

The performance of the improved head is greatly improved. Figure 17 illustrates this using the force-displacement curves of the punch during the impact. The arches resist snap-through buckling of the elliptical tank head, making the improved design much stiffer. Integrating the characteristic to obtain the energy absorption reveals that the improved design absorbs 8 times as much impact energy as the baseline tank head. The deformed baseline head is shown in Figure 18. The blunting effect of the outer sandwich panel is evident from the deformed plot in Figure 19.

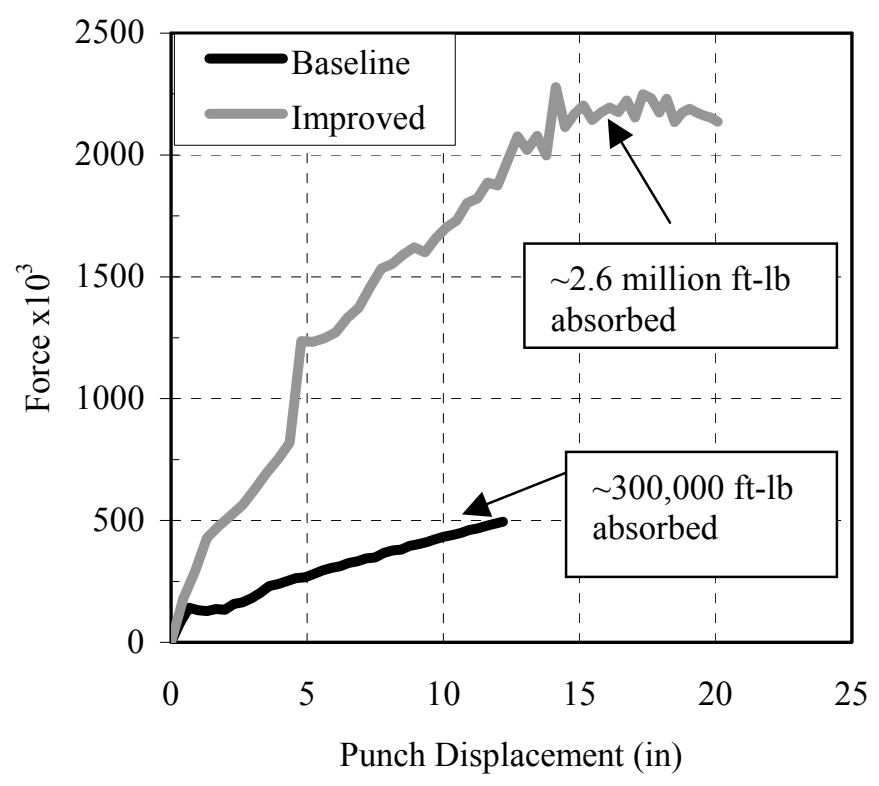

Figure 17 - Comparison of Head Impact Forcedisplacement for Baseline and Improved Tank Car

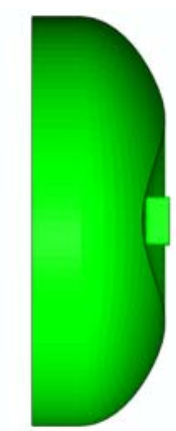

Figure 18 - Section View of Baseline Design Head Impact Analysis at Assumed Failure Point

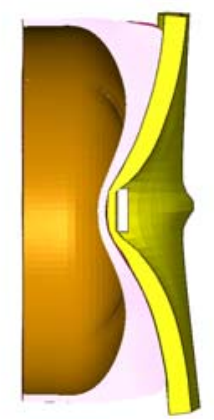

Figure 19 - Section View of Improved Design Head Impact Analysis at Assumed Failure Point

\section{Shell Impact Results}

In Figure 20, the improved tank car design shows increased strength and energy absorption in shell impacts as well, although the improvement is more modest than seen in the head impact scenario. The corrugated plate reinforcement on the tank (illustrated in Figure 6) strengthens the improved design significantly in the longitudinal direction; however, strengthening the tank circumferentially is difficult to do without adding a large amount of weight. The absorbed energy of the improved design is approximately 4.5 times greater than the baseline tank car, which fulfills the performance objective. The blunting effect of the outer carbody sandwich panel, visible in the deformed plot in Figure 21, serves to delay the rupture point of the force-displacement curve and increases the total impact energy absorption.

This material is declared a work of the U.S. Government and is not subject to copyright protection in the United States. Approved for public release; distribution is unlimited. 


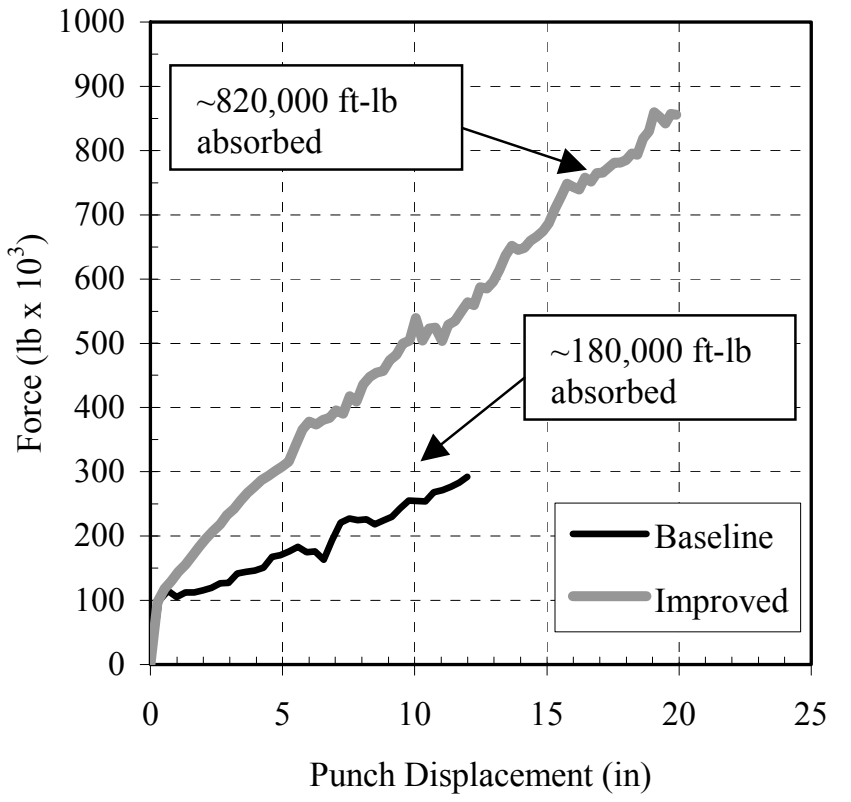

Figure 20 - Comparison of Shell Impact Forcedisplacement for Baseline Tank and Improved Tank Car

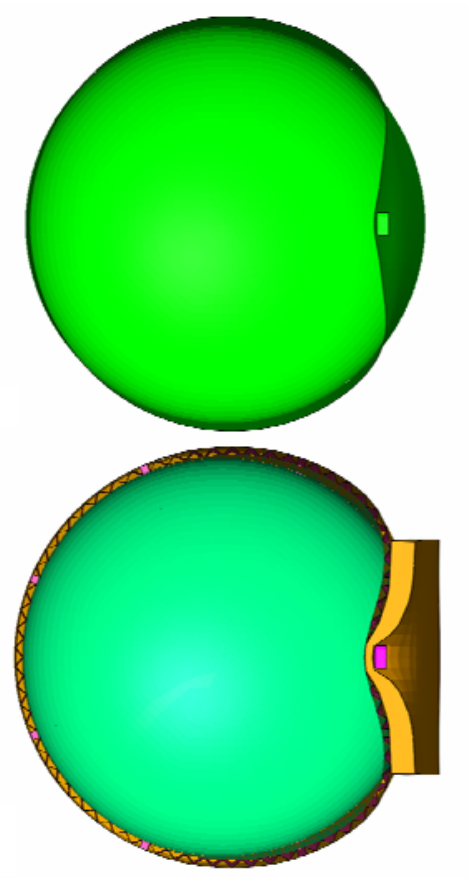

\section{Figure 21 - Above: Baseline Shell Impact at Assumed} Failure Point

\section{Below: Improved Design Shell Impact at Assumed Failure Point}

\section{SUMMARY AND NEXT STEPS}

A preliminary design for a railroad tank car capable of absorbing four times the collision energy of a conventional car has been developed. This design incorporates four functions that work together to improve the crashworthiness of the car: ability to blunt the impact load, energy-absorption capabilities, a reinforced commodity tank, and an external carbody.

This design utilizes a number of existing tank car components and manufacturing practices, including the commodity tank and draft components. Additional manufactured parts are welded steel sandwich panels, which serve as the tank's reinforcement as well as the external carbody. The sandwich panels can be manufactured at the site of the tank components or at a separate manufacturing facility. The tank may be manufactured in an existing facility, with the addition of the reinforcement panels at the end of the assembly process. The integration of the reinforced tank and the carbody is the final step in the assembly of the preliminary design.

Initial simulations of the generalized impact scenarios indicate that the performance objective is attainable with the preliminary design. Following this success, each component may now be specified and examined in greater detail. Accordingly, the next iteration of modeling will include greater complexity, with increased geometric detail, a fluid-filled pressurized tank, and material failure.

Component-level testing is being planned to verify the modeling of critical and difficult-to-analyze components. The tank car design will be refined, as determined to be appropriate from the results of the detailed analysis and testing.

\section{ACKNOWLEDGEMENTS}

The work described in this paper was sponsored by FRA Office of Research and Development. Ms. Claire Orth is the Chief of the Equipment and Operating Practices Division. Mr. Francisco Gonzalez is the FRA program manager for research on railroad tank cars.

Mr. Grady Cothen, Deputy Associate Administrator for Safety Standards and Program Development, FRA, is leading the effort to develop tank car safety standards. Mr. Eloy Martinez, FRA program manager, is developing the technical information needed to support the FRA and PHMSA rulemaking effort. The authors thank Ms. Jo Strang, Associate Administrator for Safety Enforcement, FRA, for her efforts to coordinate the standards development and the tank car safety research.

Dr. David Jeong, Senior Engineer, Volpe Center, is leading the effort to evaluate the performance of baseline equipment. The authors would like to thank Professor A. Benjamin Perlman, Senior Engineer, Volpe Center, for his assistance through all aspects of this project. The authors also wish to thank Kari Jacobsen, Mechanical Engineer, Volpe Center, for developing the target kinematics and energy absorption goals, Michelle Priante, Mechanical Engineer, Volpe Center, for assisting with the concept generation, and Philip Mallon, Mechanical Engineer, Volpe Center, for researching sandwich structures and weight-efficient methods of energy absorption.

\section{REFERENCES}

This material is declared a work of the U.S. Government and is not subject to copyright protection in the United States. Approved for public release; distribution is unlimited. 
[1] Tyrell, D.C., Jacobsen, K., Talamini, B., Carolan, M., "Developing Strategies for Maintaining Tank Car Integrity During Train Accidents," Proceedings of the 2007 ASME Rail Transportation Division Fall Technical Conference, RTDF2007-46015, September 2007.

[2] Tang, Y.H., Yu, H., Gordon, J.E., Priante, M., Jeong, D.Y., Tyrell, D.C., Perlman, A.B., "Analysis of Full-Scale Tank Car Shell Impact Tests," Proceedings of the 2007 ASME Rail Transportation Division Fall Technical Conference, RTDF2007-46010, September 2007.

[3] Yu, H., Jeong, D.Y., Gordon, J.E., Tang, Y.H., "Analysis of Impact Energy to Fracture Un-Notched Charpy Specimens Made from Railroad Tank Car Steel," Proceedings of the 2007 ASME Rail Transportation Division Fall Technical Conference, RTDF2007-46038, September 2007.

[4] Jeong, D.Y., Lyons, M.L., Orringer, O., Perlman, A.B., "Equations of Motion for Train Derailments," Proceedings of the 2007 ASME Rail Transportation Division Fall Technical Conference, RTDF2007-46009, September 2007.

[5] Tyrell, D.C., Jeong, D.Y., Jacobsen, K., Martinez, E., "Improved Tank Car Safety Research," Proceedings of the 2007 ASME Rail Transportation Division Fall Technical Conference, RTDF2007-46013, September 2007.

[6] Tang, Y, Yu, H, Gordon, J, Jeong, D, Perlman, A.B., "Analysis of Railroad Tank Car Shell Impacts Using Finite Element Method," Proceedings of the 2008 ASME/IEEE Joint Rail Conference, JRC2008-63014, April 2008.

[7] Ashby, M.F., Evans, A.G., Fleck, N.A., Gibson, L.J., Hutchinson, J.W., Wadley, H.N.G. "Metal Foams: A Design Guide," Butterworth-Heinemann: London, 2000.

[8] Wadley, H.N.G., Fleck, N.A., Evans, A.G., "Fabrication and Structural Performance of Periodic Cellular Metal Sandwich Structures," Composite Science and Technology 63, 2003.

[9] Jeong, D.Y., Tang, Y.H., and Perlman, A.B., "Engineering Analyses of Railroad Tank Car Head Puncture," Proceedings of 2006 ASME International Mechanical Engineering Congress and Exposition, November 5-10, 2006.

[10] Association of American Railroads, Technical Services Division, Mechanical Section - Manual of Standards and Recommended Practices.

[11] Abaqus Version 6.7. Providence: Dassault Systèmes, 2007.

[12] Fleck, N.A., Deshpande, V.S. "Isotropic constitutive models for metallic foams," Journal of the Mechanics and Physics Solids, 48:1253-1283. 2000.

[13] Xue, Z., Hutchinson, J.W. "Preliminary assessment of sandwich plates subject to blast loads," International Journal of Mechanical Sciences, 45, 687-705. 2003.

[14] Xue, Z., Hutchinson, J.W. "Constitutive model for quasistatic deformation of metallic sandwich cores," International Journal for Numerical Methods in Engineering. 61:2205-2238. October 2004.

\section{APPENDIX}

The Deshpande-Fleck metal foam model is a reasonable approximation of the aggregate behavior of the carbody sandwich panel cores in impacts since it allows volume change during plastic deformation. In this paper, it is calibrated to reproduce the crushing behavior of a structural sandwich core, following essentially the same procedure as Xue and Hutchinson [13]. Refer to this paper for a more detailed derivation.

The yielding criterion in the Deshpande-Fleck model is determined by an effective stress $\sigma_{e}$, defined as

$\sigma_{e}^{2}=\frac{1}{1+(\alpha / 3)^{2}}\left[\sigma_{v m}^{2}+\alpha^{2} \sigma_{m}^{2}\right]$

where $\sigma_{v m}$ is the standard von Mises stress and $\sigma_{m}$ is the mean normal stress. Yielding occurs when the effective stress equals the yield strength of the material. The parameter $\alpha$ controls plastic compressibility by defining a "plastic Poisson's ratio" $v^{p}=-\varepsilon_{\text {lat }}^{p} / \varepsilon_{\text {long }}^{p}$ through the relation

$\alpha=3 \sqrt{\frac{1 / 2-v^{p}}{1+v^{p}}}$

A value of $v^{\mathrm{p}}=1 / 2$, corresponding to $\alpha=0$, models the material as plastically incompressible - as in the case of standard metal plasticity - and the effective stress reduces to the von Mises stress. In the present case, $v^{\mathrm{p}}$ is taken to be zero $\left(\alpha=3 / 2^{1 / 2}\right)$, since the crushing strain of the sandwich core is virtually independent of the in-plane strains.

The effective yield strength and elastic properties of the core material are estimated analytically after specifying the geometry of the core. Square honeycomb was chosen for improved design since it is equally strong in both in-plane directions. A schematic of square honeycomb is shown in Figure A1. The goal here is to replace the core webs with approximately equivalent continuum elements (see Figure A2).

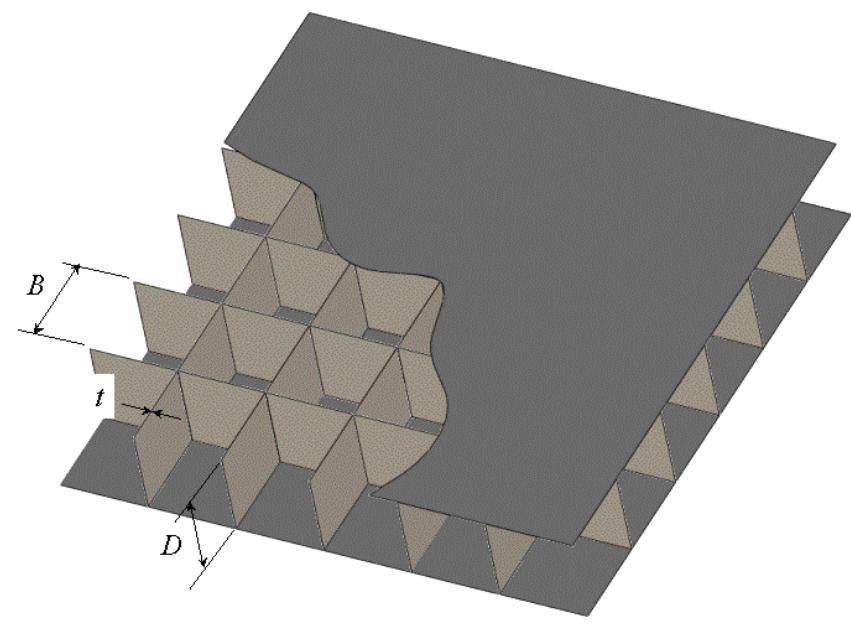

Figure A1 - Square honeycomb sandwich panel

This material is declared a work of the U.S. Government and is not subject to copyright protection in the United States. Approved for public release; distribution is unlimited. 

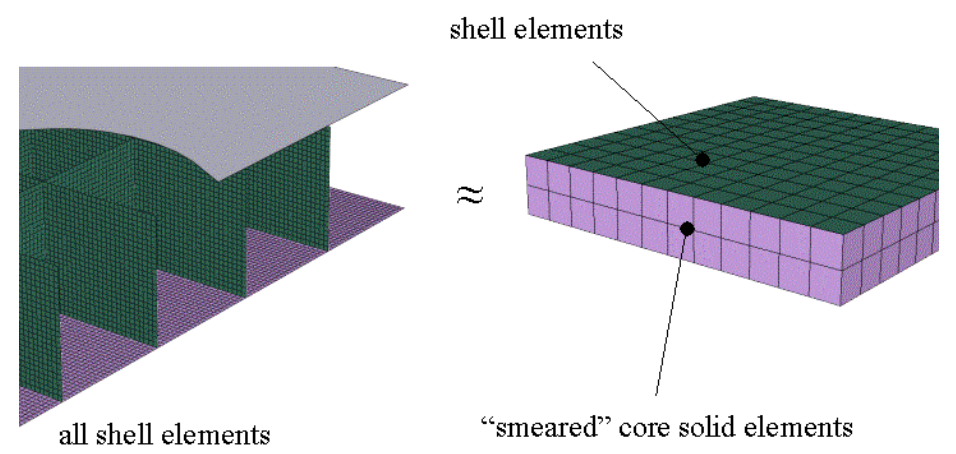

Figure A2 - Continuum core approximation

Referring to Figure A1, the core web thickness is $t$ and the core web width is $B$. The relative density of the core (the ratio of the average density of the core to the density of the core material, or equivalently, the fraction of solid material in the core compared to the core volume) is $\bar{\rho}_{c}$, and is given by

$\bar{\rho}_{c}=2 \frac{t}{B}-\left(\frac{t}{B}\right)^{2}$

The nominal uniaxial stress in the core volume during compression of the sandwich panel under an overall stress of $\sigma$ is

$$
\sigma_{\text {nom }}=\bar{\rho}_{c} \sigma
$$

The nominal yield strength of the smeared core material $\sigma_{c}^{Y}$ is therefore

$$
\sigma_{c}^{Y}=\bar{\rho}_{c} \sigma_{Y}
$$

The crush strength of the chosen core is 600 psi. This crush strength is a result of the core geometry and available weight for the core. The core geometry was chosen to be a 6 inch by 6 inch by 6 inch egg-crate arrangement, shown in Figure A1. For simplicity, the tank car material TC-128B was chosen for the sandwich panel, with $\sigma_{Y}=50 \mathrm{ksi}$. Using this yield strength and the desired core strength in (A5), the relative density may be computed as $\bar{\rho}_{c}=0.012$. (A3) may now be solved for $t / B$, yielding one useful root of $t / B \approx 0.006$. Choosing 6 inches for the web width $B$, the corresponding web thickness is $0.036 \mathrm{in}$. The core depth $D$ can be chosen freely, and was selected as 6 inches based on geometric restrictions on the railcar from regulations and industry standards.

The effective elastic modulus of the core $E_{c}$ in the crushing direction is

$$
E_{c}=\bar{\rho}_{c} E
$$

This value was used in the present work. Alternatively, the effective elastic modulus could be set to the in plane behavior, which is half of the value computed from (A6), since half of the webs are aligned in either in-plane direction. The Poisson's ratio was taken to be zero.

The hardening behavior of the core material must be characterized to fully specify the Deshpande-Fleck model. The hardening curve is assumed to behave like Figure A3, based on a similar core studied in [14] (note that the strain measure is logarithmic, not nominal). The steep hardening slope at an equivalent plastic strain of 1.4 (a nominal strain of approximately $75 \%$ ) characterizes the panel response after total collapse of the webs.

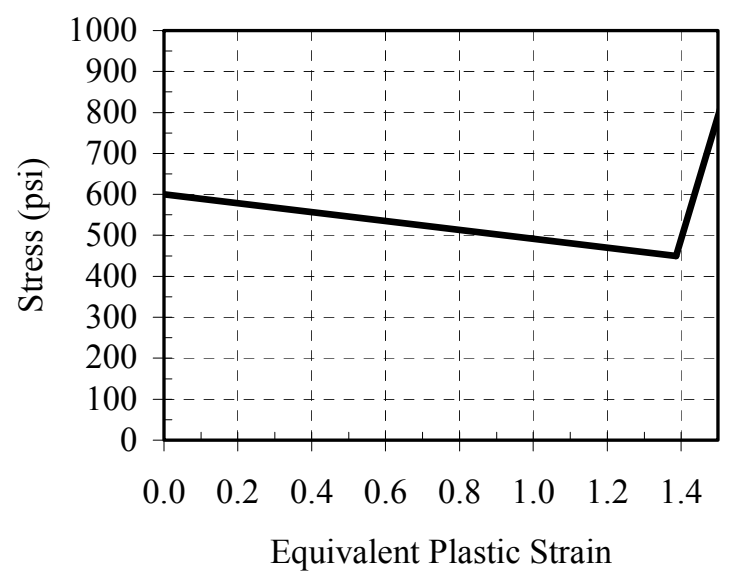

Figure A3 - Effective hardening curve for core elements

Finally, the effectiveness of structural sandwich panels can be seen from the details of this procedure. The average strength of the core in the present design is about $500 \mathrm{psi}$, with a density of approximately $6 \mathrm{lb} / \mathrm{ft}^{3}$. These values compare favorably to alternative sandwich panels cores of metal foams and polymer foams.

This material is declared a work of the U.S. Government and is not subject to copyright protection in the United States. Approved for public release; distribution is unlimited. 